\title{
Forensic Examination of Benzodiazepines: A Case Study
}

\author{
Ritu Malik ${ }^{1 *}$, Komal Singh ${ }^{1}$ and Amit Rawat ${ }^{2}$ \\ ${ }^{1}$ Department of Zoology, Kurukshetra University, India \\ ${ }^{2}$ Assistant Director Chemistry and Toxicology Division, Forensic Science Laboratory, India
}

Submission: February 07, 2018; Published: April 26, 2018

*Corresponding author: Ritu Malik, Department of Zoology, Kurukshetra University, Kurukshetra, India, Email: rmalik81293@gmail.com

\begin{abstract}
Benzodiazepines are currently among the most frequently prescribed drugs all over the world. These drugs are misused because of their wide variety of color, have no specific smell, hence easy to mix with any eatabe and can be easily available without prescription. Considering their increased potential for addiction and abuse in case of crime, suicide and drug facilitated sexual assault. Benzodaizepines are a class of psychoactive drugs whose core chemcial structure is the fusion of benzene ring and a diazepene ring. In this study, sedatives were extracted from cream biscuits using drug extraction procedure and analysed using thin layer chromatography (TLC) and Fourier Transform Infrared Spectrometry (FTIR). In extraction procedure, Diethyl ether and chloroform (3:1) were used. In TLC, two solvent systems Chloroform: Methanol (9:1) and Ethyl acetate: Methanol: Ammonia (15:5:0.5) were used. FTIR spectrum analysis also confirmed the match of suspected sample with the standard Lorazepam. Benzodiazepines are challenging to analyse in FTIR because of their varied color which sometimes interfere to give appropriate results. Therefore, the separation and identification of these compounds is of great interest and it is important to develop an efficient sample preparation procedure as well as method able to determine benzodiazepines in different matrices.
\end{abstract}

Keywords: Benzodiazepines; TLC; FTIR; Drug analysis; GABA receptors

\section{Introduction}

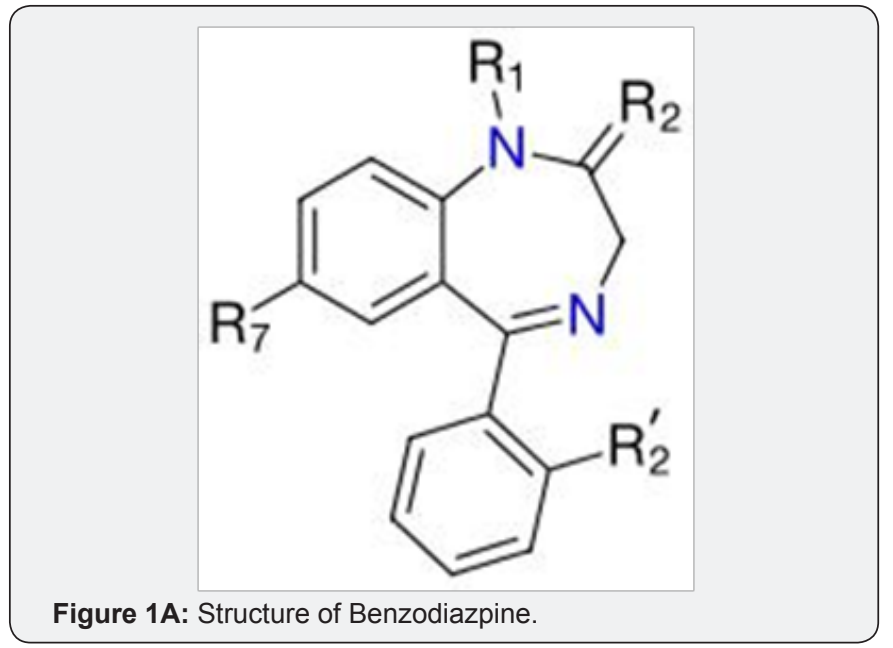

Benzodiazepines are a class of psychoactive drugs whose core chemical structure is the fusion of benzene ring and a diazepene ring. Drug is any substance or product that is used or intended to be used to modify or explore physiological systems or pathological states for the benefit of recipients. Chlordiazepoxide (Librium) was the first of the benzodiazepines discovered by Leo Sternbach (1965) to be marketed as a sedative and an anxiolytic. They enhance the inhibitory actions of the neurotransmitter gamma-amino butaric acid (GABA), located in the brain [1-4]. These drugs are extensively absorbed when taken orally and achieve peak blood concentrations in about 1 hour. Benzodiazepines become highly protein bound after absorption. Many of them are metabolized and excreted into bile from which they may undergo reabsorption back into the blood (Figure 1A).

Mechanism of action: GABA controls the excitability of neurons by binding to the GABAA receptor. The GABAA receptor is a protein complex located in the synapses of neurons. All GABAA receptors contain an ion channel that conducts chloride ions across neuronal cell membranes and two binding sites for the neurotransmitter gamma-aminobutyric acid (GABA) $[5,6]$. The GABAA receptor is a heteromer composed of five subunits, the most common ones being two $\alpha$ s, two $\beta$ s, and one $\gamma(\alpha 2 \beta 2 \gamma)$. Benzodiazepines bind at the interface of $\alpha$ and $\gamma$ subunits on the GABAA receptor. Benodiazepines once bound to the benzodiazepine receptor, the benzodiazepine ligand locks the benzodiazepine receptor into a conformation in which it has a greater affinity for the GABA neurotransmitter. This increases the frequency of the opening of the associated chloride ion channel and hyperpolarizes the membrane of the associated neuron [7].

The inhibitory effect of the available GABA is potentiated, leading to sedatory and anxiolytic effects. For instance, those 
ligands with high activity at the $\alpha 1$ are associated with stronger hypnotic effects, whereas those with higher affinity for GABAA receptors containing $\alpha 2$ and/or $\alpha 3$ subunits have good antianxiety activity (Figure 1B \& 1C).

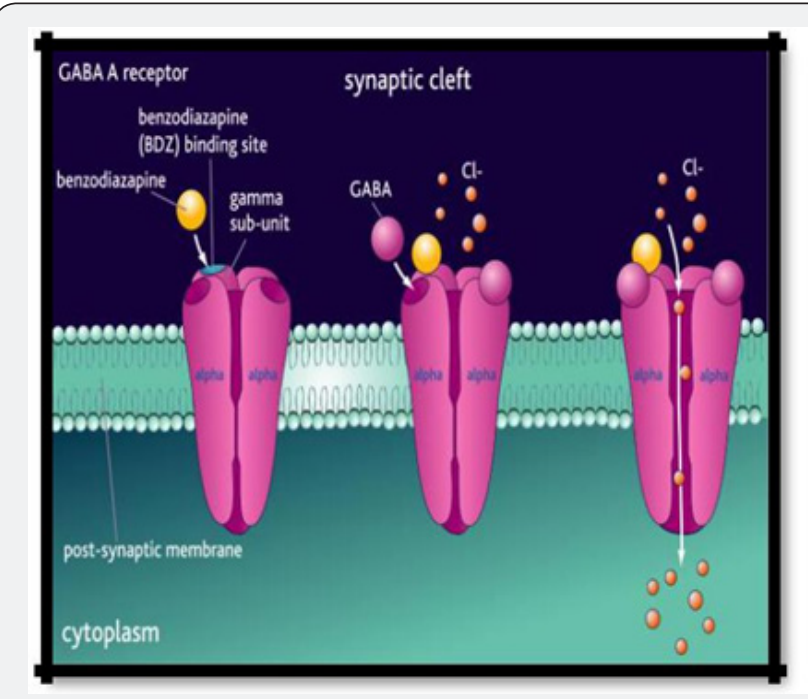

Figure 1B: Mechanism of Benzodiazepines.

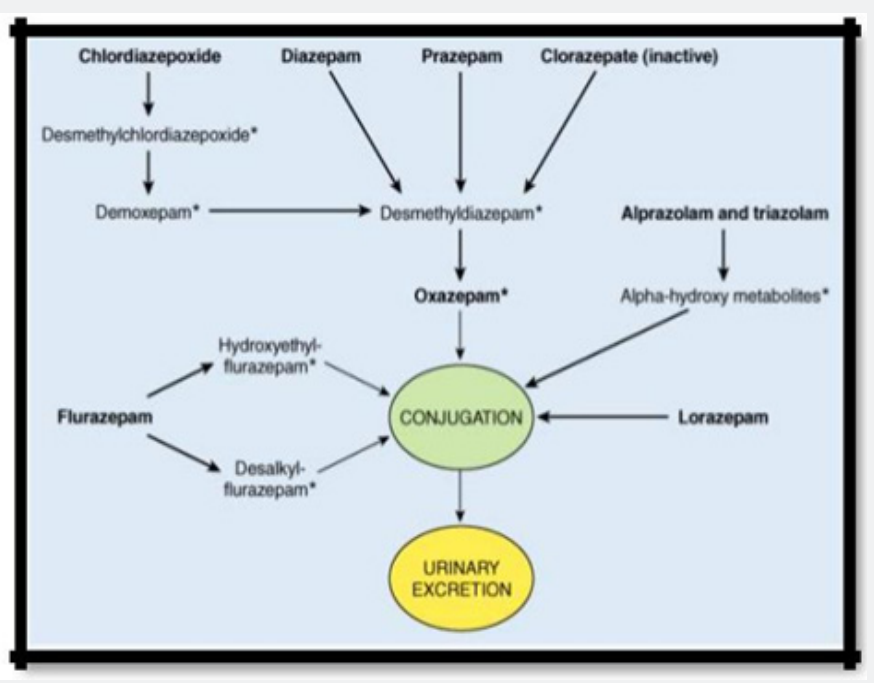

Figure 1C: Metabolism of Benzodiazepines.

Routes of Administration are oral, injection, smoking, rectal administration. Fatal dose of benzodiazepines is 100 to $300 \mathrm{mg} /$ $\mathrm{kg}$ body weight. It is used for medical purposes such as seizures, insomnia, general anesthesia, muscle relaxation, alcohol withdrawal, panic attacks etc. Symptoms found after intake of these drugs are vertigo, sleep disturbance, dizziness, drowsiness, loss of orientation, memory impairment, aggression, irritiability, slurred speech, nystagmus, diplopia, dysarthria, ataxia, staggering walk, shallow breathing, sedation, somnolecence, comma, muscle spasms, convulsions, vomiting etc. The commonly used Benzodiazepines are Diazepam, Flurazepam, Chlordiazepoxide, Nitrazepam, Oxazepam, Alprazolam and Lorazepam $[8,9]$.

\section{Case Study}

Some people have found new tricks to deprive trains and bus passengers of their cash and valuables. These crooks are using any form of eatable including buy offerings (Prasad), ladoo, biscuits or soft drinks as a bait to rob passengers.

On Jan 19. Kunal, resident of Rohini West, New Delhi was drugged through biscuit in a train and then robbed. He was on his way to home from Akshardham Mandir, New Delhi. He told the police that, the stranger seated next to him offered biscuits. Few minutes after eating biscuits he became drowsy and lost consciousness. He does not remember anything. Next day, he found himself in hospital with a glucose drip on. The crook escaped with victims' bag containing Rs. 5000, laptop and some official files. Hospital authorities diagnosed Kunal illness as consumption of sedatives. Police found opened biscuit packet from the place of crime with still two cream biscuits left which they forwarded to FSL in sealed condition for further opinion on whether it contain any sedative or not [10-13].

\section{Materials and Methods}

Cream biscuit which was the suspected sample found at the crime scene at New Delhi was used as the sample and sedatives were extracted using drug extraction procedure and analysed using thin layer chromatography (TLC) and Fourier Transform Infrared Spectrometry (FTIR).

a) Extraction Procedure: Crushed cream biscuits were taken in an evaporating dish. $50 \mathrm{ml}$ of distilled water was added and shaken properly. This mixture was filtered and transferred into the separating funnel. $90 \mathrm{ml}$ of Diethylether and $30 \mathrm{ml}$ of Cholorform (3:1) was added into the filterate in a separating funnel and shaken properly. Lower aqueous layer was taken out. Upper organic layer was passed through sodium sulphate anhydrous in an evaporating dish. Air dried the evaporating dish.

b) Thin Layer Chromatgraphy: TLC plate was cut $(10 \mathrm{~cm} \times 20 \mathrm{~cm})$ and activated by keeping it in the oven for 20 minutes. Solvent systems were prepared using Choroform: Methanol (9:1). The TLC chamber was filled to a depth of about one $\mathrm{cm}$ from the bottom and allowed to saturate. A vertical line of $1.5 \mathrm{~cm}$ was drawn apart from the bottom of the TLC plate. Purified extract dissolved in chloroform were serially spotted on the vertical line of the TLC plate along with the standards (phenargan, DAM, diazepam (basic), lorazepam (basic), nitrazepam (basic). Allowed the TLC plate to run. The plates were removed from the chamber and mark the solvent front immediately with the pencil and let the solvent dried off the plate. TLC plates were visualized under UV light (254 $\mathrm{nm}$ ) for characteristics fluorescence or absorbance. Sprayed the spraying reagent Dragendroff and the Rf values for each spot was calculated. The whole process was revised for second solvent system using Ethyl 


\section{Open Access Journal of Toxicology}

acetate: Methanol: Ammonia (15:5:0.5) on the basis of initial results.

c) FTIR: $\mathrm{KBr}$ pellets were prepared using $\mathrm{KBr}$ powder mixed with extracted samlple. Scan the KBr pellets in FTIR.

\section{Results and Discussions}

Considering that benzodiazepines can harm the people if misused, on the basis of the case study, analysis of suspected sample was done using Thin Layer Chromatography and Fourier Transform. In TLC by calculating Rf value comparison was made and in FTIR principle peak values of sample and standard were compared.

\section{Thin layer chromatography}

Solvent system 1: Chloroform: Methanol (9:1) (Figure 2 \& 3 , Table 1)

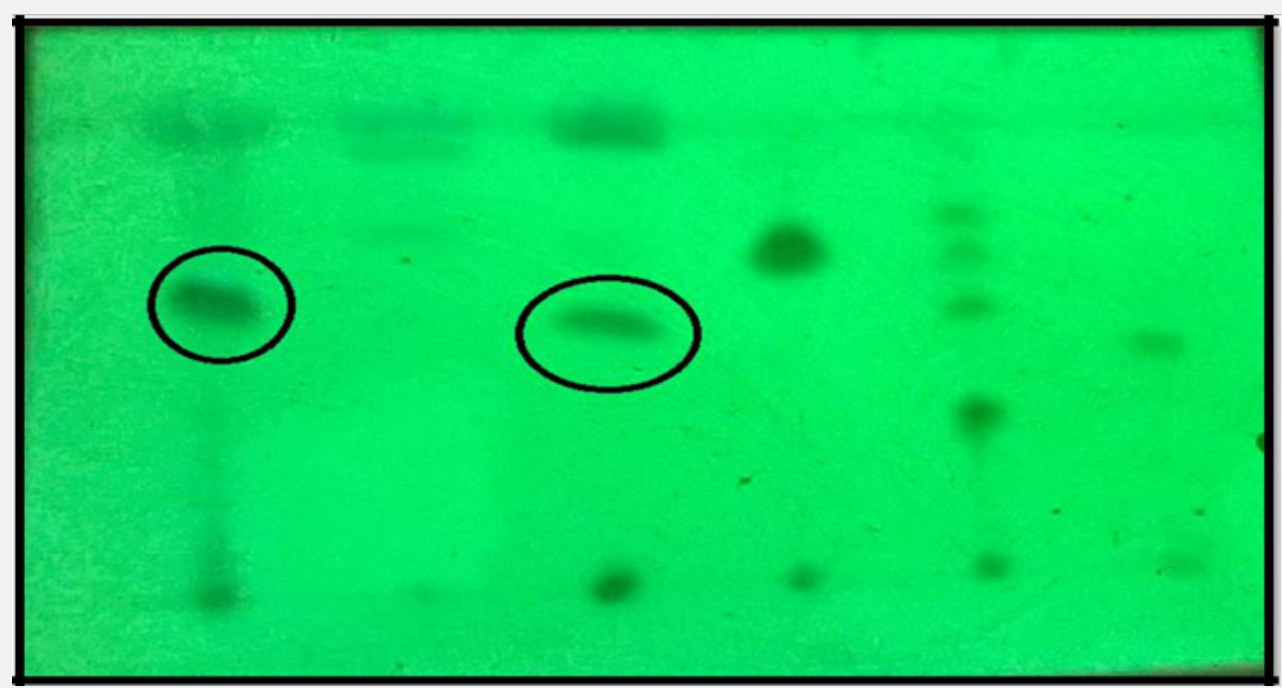

Figure 2: Showing TLC plate under UV Light: Chloroform: Methanol (9:1).

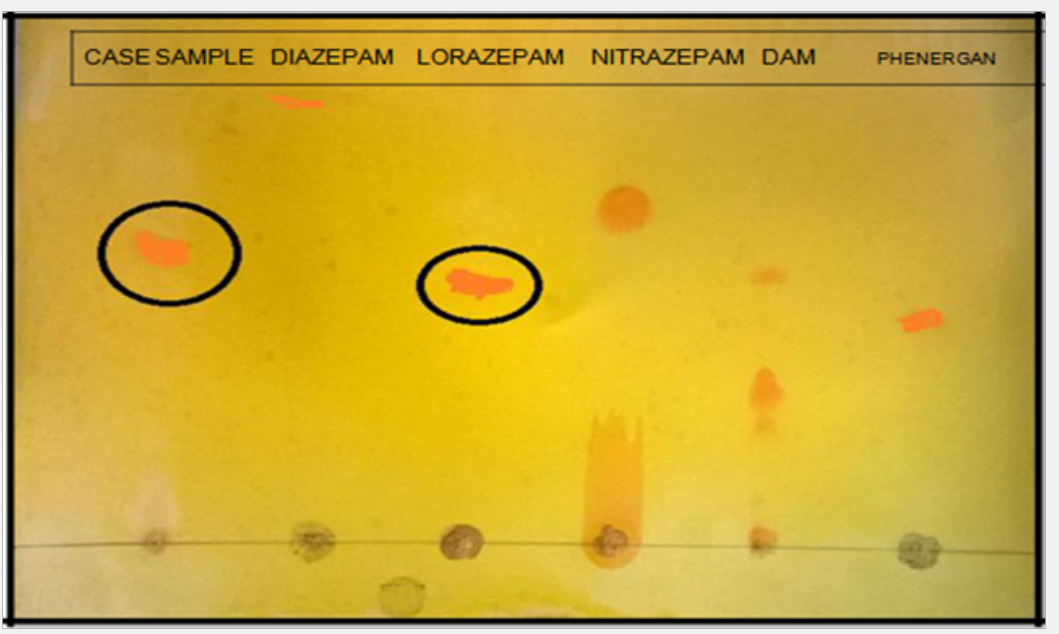

Figure 3: Showing TIC plate after spraying with Dragendroff: Chloroform: Methanol (9:1).

Table 1: Rf value of different Benzodiazepines in solvent system Chloroform: Methanol (9:1).

\begin{tabular}{|c|c|c|c|}
\hline Benzodiazepines & $\begin{array}{c}\text { Distance Travelled By Solvent } \\
\text { (cm) }\end{array}$ & $\begin{array}{c}\text { Distance Travelled By Solute } \\
\text { (cm) }\end{array}$ & Rf Value \\
\hline Case Sample & 8 & 4.4 & 0.55 \\
\hline Diazepam & 8 & 6.5 & 0.81 \\
\hline Lorazepam & 8 & 4.3 & 0.53 \\
\hline Nitrazepam & 8 & 5 & 0.62 \\
\hline Dam & 8 & 1.8 & 0.22 \\
\hline Phenergan & 8 & 3.4 & 0.42 \\
\hline
\end{tabular}

On the basis of above table Rf value of Case sample is almost similar to the Rf value of standard Lorazepam. 


\section{Open Access Journal of Toxicology}

Solvent system 2: Ethylacetate: Methanol: Ammonia (15:5:0.5) (Figure 4 \& 5, Table 2)
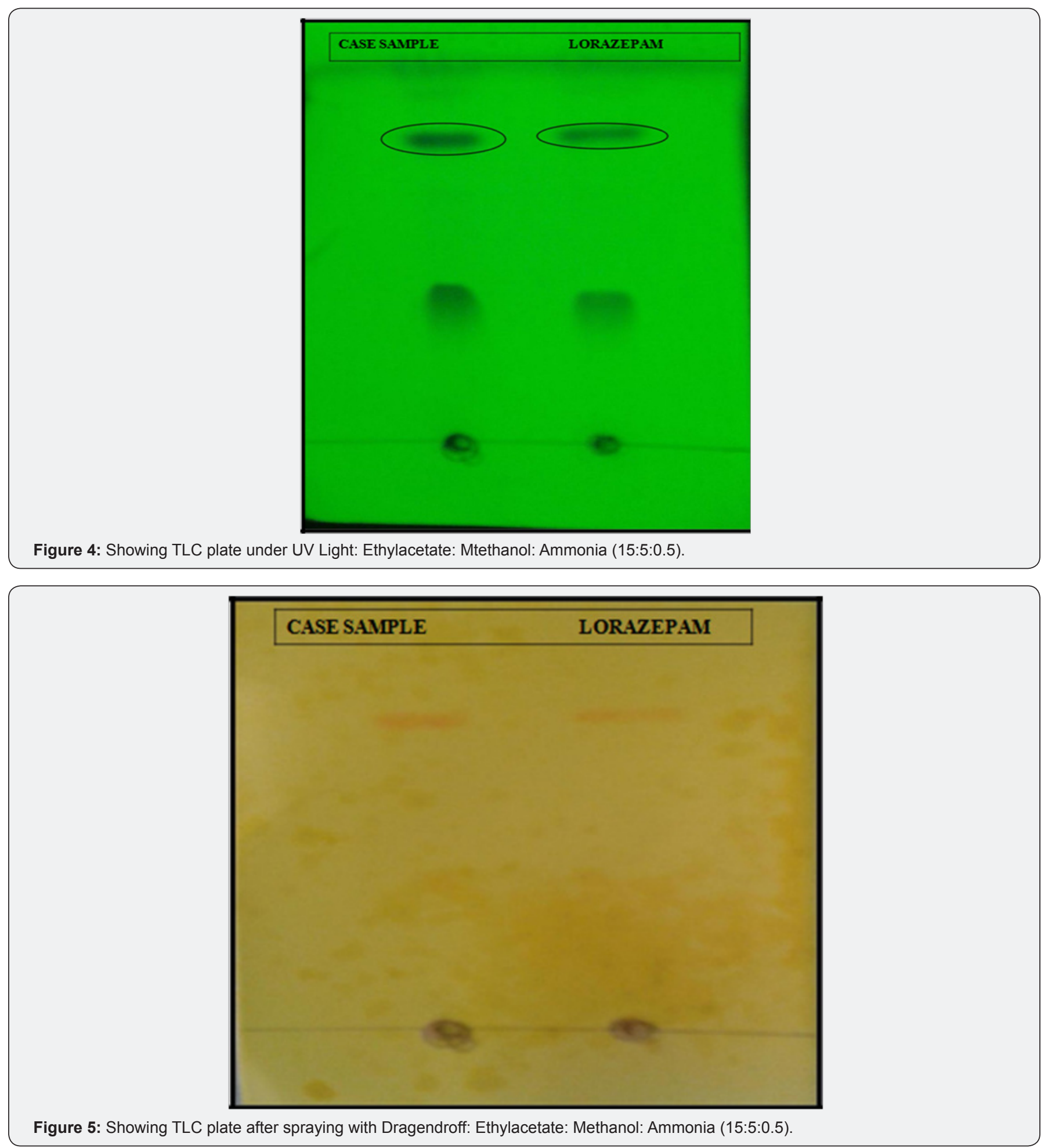

Table 2: Rf value of different Benzodiazepines in solvent system Ethylacetate: Methanol: Ammonia (15:5:0.5).

\begin{tabular}{|c|c|c|c|}
\hline Benzodiazepines & $\begin{array}{c}\text { Distance Travelled By Solvent } \\
\text { (cm) }\end{array}$ & $\begin{array}{c}\text { Distance Travelled By Solute } \\
\text { (cm) }\end{array}$ & Rf Value \\
\hline Case Sample & 8.3 & 7.7 & 0.92 \\
\hline Lorazepam & 8.3 & 7.7 & 0.92 \\
\hline
\end{tabular}

On the basis of above table Rf value of Case sample is exactly similar to the Rf valur of standard Lorazepam i.e. 0.92. Hence the suspected sample is confirmed to be Lorazepam. 
Fourier Transform Infrared Spectrometry (Figure $6 \&$ 7, Table 3)

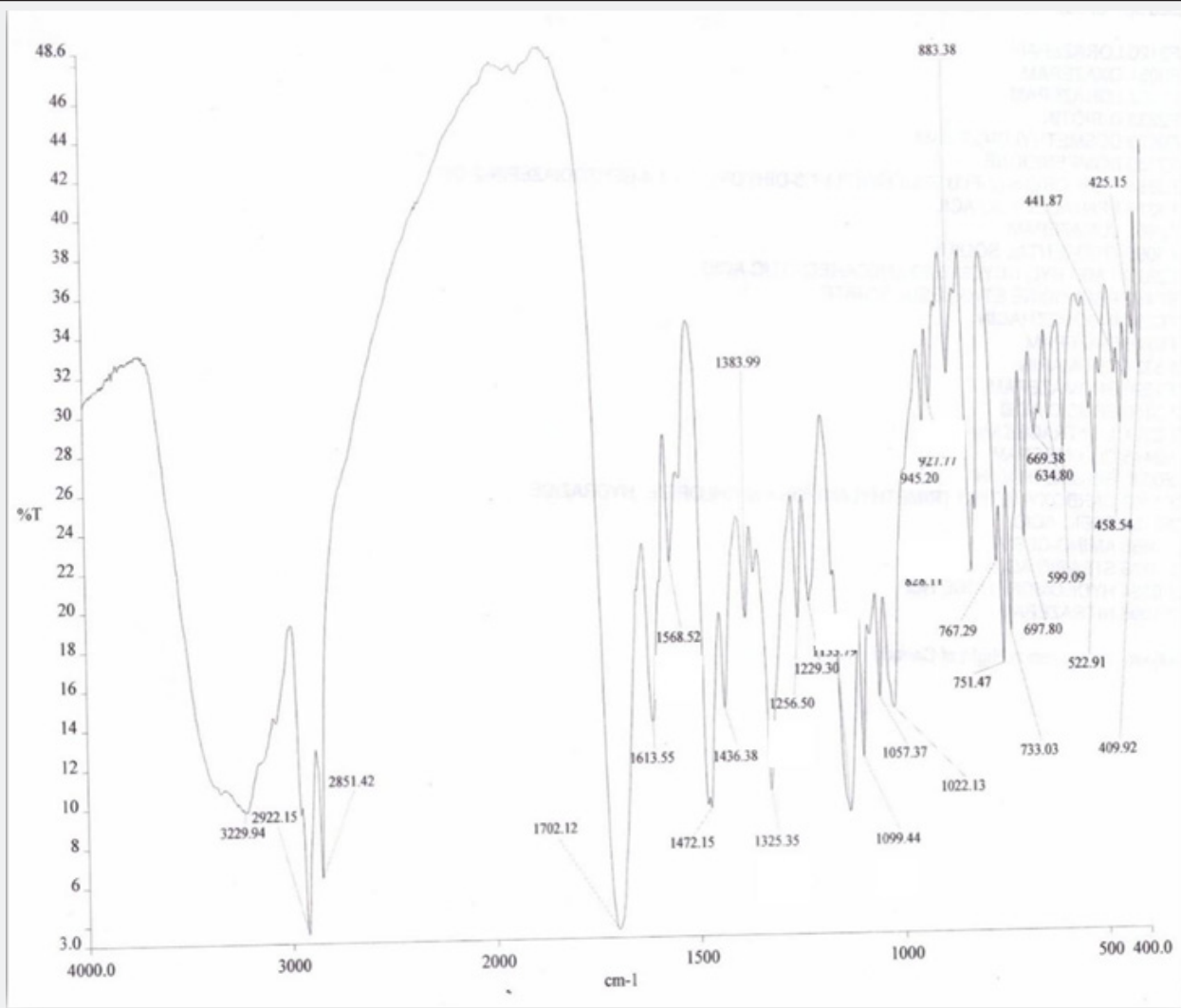

Figure 6: Showing interferogram for the extracted case sample.

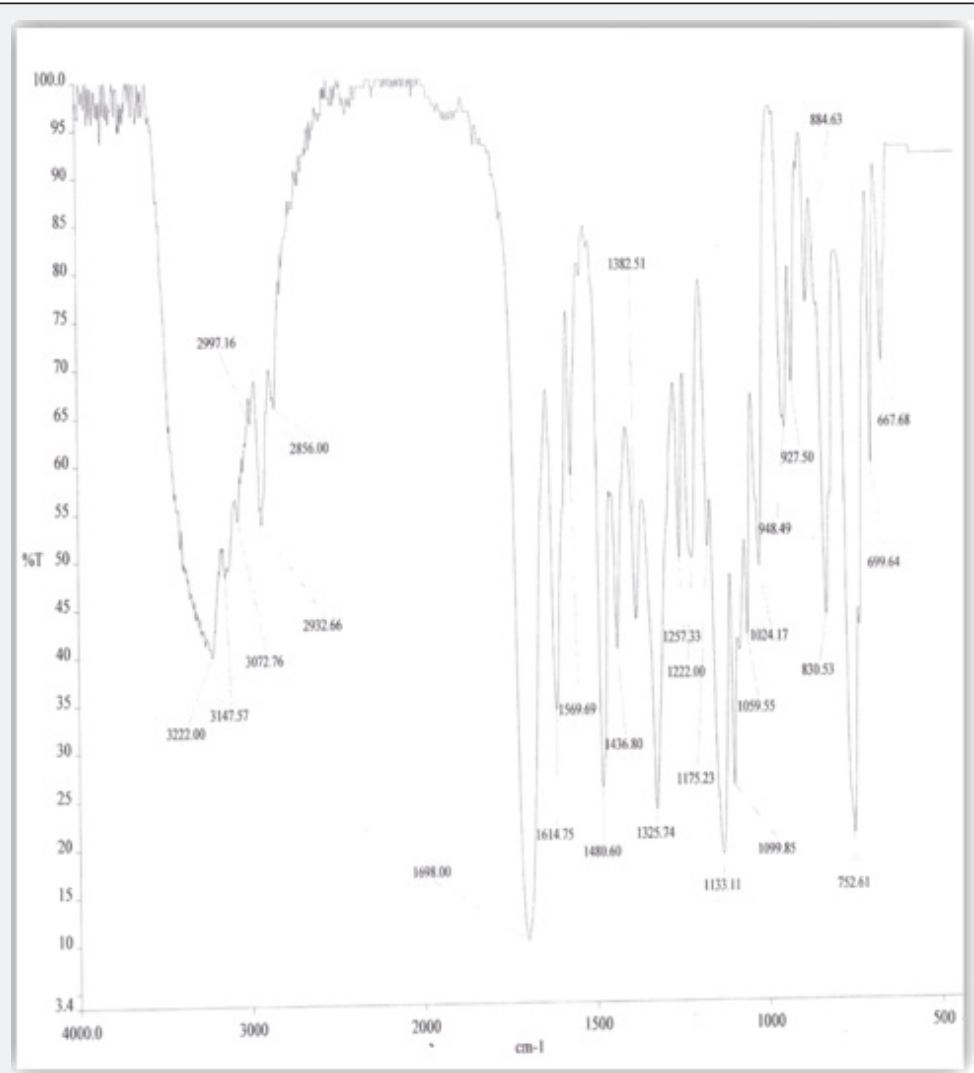

Figure 7: Showing interferogram for the standard Lorazepam. 


\section{Open Access Journal of Toxicology}

Table 3: Match of principle peaks in FTIR spectrum of extracted sample and standard Lorazepam ( $\left.\mathrm{cm}^{-1}\right)(\mathrm{KBr}$ disk).

\begin{tabular}{|c|c|c|}
\hline & \multicolumn{2}{|c|}{ Principle Peaks } \\
\hline No. & Extracted Sample $\mathbf{( c m}^{-1} \mathbf{)}$ & Standard Lorazepam $\left(\mathbf{c m}^{-1}\right)$ \\
\hline 1 & 1702.12 & 1698 \\
\hline 2 & 1613.55 & 1569.69 \\
\hline 3 & 1568.52 & 1436.8 \\
\hline 4 & 1436.38 & 1325.74 \\
\hline 5 & 1325.35 & 1257.33 \\
\hline 6 & 1256.5 & 1133.11 \\
\hline 9 & 1133.79 & 1099.85 \\
\hline 10 & 1099.44 & 927.5 \\
\hline
\end{tabular}

\section{Conclusion}

On the basis of the case study given, sedatives were extracted from the cream biscuits using drug extraction procedure and analyzed using thin layer Chromatography (TLC) and Fourier Transform Infrared Spectrometry (FTIR). In extraction procedure, Diethyl ether and chloroform (3:1) were used because of the solubility of drugs in them. In TLC two solvent systems Chloroform: Methanol (9:1) and Ethyl acetate: Methanol: Ammonia (15:5:0.5) were used for the confirmation of the sedative found. By analyzing Rf value comparison was made. Rf value of Lorazepam was similar to that of extracted sample i.e. $0.53 \pm 0.2$ and $0.55 \pm 0.2$ respectively in the solvent system Chloroform: Methanol (9:1). Rf value of extracted sample was exactly similar to the standard Lorazepam i.e. $0.92 \pm 0.2$ in the solvent system Ethyl acetate: Methanol: Ammonia (15:5:0.5). $\mathrm{KBr}$ pellets (inert in Infra red Spectrum) were for confirmation of Lorazepam using FTIR technique. In FTIR spectrum nearly 10 principal peaks of suspected sample were matched with the standard Lorazepam like $1133.79 \mathrm{~cm}^{-1}$ (Sample), $1133.11 \mathrm{~cm}^{-1}$ (Standard), $828.11 \mathrm{~cm}^{-1}$ (Sample) and $830.53 \mathrm{~cm}^{-1}$ (Standard) (as shown in Table 3). On the basis of experimental results, it is therefore concluded that the sedative used to rob the victim Kunal was Lorazepam, a Benzodiazepine. Benzodiazepines are challenging to analyze in FTIR because of their varied color which sometimes interfere to give appropriate results. The success of benzodiazepines could be attributed to the fact that they were considered safer and less habit-forming than barbiturates. The widespread use of this class of drugs has occasionally raised concern about recreational benzodiazepine abuse and has led to the erroneous impression that benzodiazepines have a relatively high abuse liability among recreational drug users. These drugs are misused because of their wide variety of color, have no specific smell, hence easy to mix with any eatable and can be easily available without prescription. Considering their increased potential for addiction and abuse, the separation and identification of these compounds is of great interest and it is important to develop an efficient sample preparation procedure as well as method able to determine benzodiazepines in different matrices.

\section{Acknowledgement}

Foremost I pay my sincere gratitude to Dr. R.K. Sharma, Chairperson of Department of Zoology, Kurukshetra University, Kurukshetra for allowing me to work on this project and for his valuable guidance and moral support. I wish to express my humblest thanks to Dr. R.K. Sareen, Director, FSL Rohini, New Delhi for giving me permission to complete my project in his esteemed laboratory. I owe a special debt of thanks to Dr. Madhulika, Deputy Director, Head of the Chemistry Division, FSL Rohini, New Delhi for her generous help and cooperation. I also wish to express my heartfelt gratitude to my guide $\mathrm{Mr}$. Amit Rawat, Assistant Director, Chemistry Division, FSL Rohini, New Delhi who always stood by me, gave me valuable inputs and excellent guidance at all times, and devoted time and efforts to complete my project. I also wish to express my heartfelt gratitude to Mr. Sourav, Lab Assistant, Chemistry Division, FSL Rohini, New Delhi for his generous help. I am highly grateful to my teachers, Mr. Suryakant Mishra, Dr. Manavpreet Kaur and Dr. Praveen Kumar, for providing help and valuable suggestions to make this study successful. Furthermore, I am truly thankful to my parents and my friends for their continuous support and immense cooperation.

\section{References}

1. Clarke (2008) Clarke's Analytical Forensic Toxicology, Pharmacuetical Press, ( $1^{\text {st }}$ edn), UK, p. 78-79.

2. Rohini Directorate of Forensic Science Manual, New Delhi, India.

3. KS Narayan Reddy, OP Murty (2014) The Essentials of Forensic Medicine and Toxicology, The Health Sciences Publishers, (33 $3^{\text {rd }}$ edn), pp. 595.

4. Encylopedia of Forensic Sciences, Elsevier, USA, P. 1-3.

5. John Joseph Fenton (2002) Toxicology: A Case-Oriented Approach, CRC Press, USA, pp: 421-426.

6. R K Sharma (2011) Forensic Medicine and Toxicology, Global Education Consultant, ( $3^{\text {rd }}$ edn), pp: 311. 
7. Matthews A, Kirkby KC, Martin F (2002) The Effects of Single- dose Lorazepam on Memory and Behavioural Learning. J Psychopharmacol 16(4): 245-254

8. DJ Greenblatt, RI Shader, M Divoll, JS Harmatz (1981) Benzodiazepines: A Summary of Pharmacokinetics Properties. Br J Clinical Pharmacol 11 Suppl: 11S-16S

9. DW Holt, AM Hayler, GF Healey (1983) The Classification of Benzodiazepines Hypnotics. Br J Clinical Pharmacol 16(3): 345-347.

10. M N Uddin, Victoria, Samanidou, IN Papadoyannis (2014) An Overview on Total Analytical Methods for the Detection of 1,4-Benzodiazepines. Journal of Pharmaceutica Analytica Acta 5(6): 2153-2435.
11. SC Turfus, RA Braithwaite, DA Coven, MC Parkin, NW Smith, et al. (2011) Metabolites of Lorazepam: Relevance of Past Findings To Present Day Use Of LC-MM in Analytical Toxicology. Drug Test Anal 3(10): 695-704.

12. SK Jain, D Samaiya, HS Maheswari, M Shodiya (2004) Benzodiazepines (Lorazepam and Oxazepam): Drug Abuse: A Biochemical Study. Advances in Life Science (Book), pp: 96-102.

13.W Weinmann, N Leihmann, C Muller, A Wiedermann, M Svoboda (2000) Identification of Lorazepam and Sildenafil as Example for the Application of LC-MS and MS-MS with Mass Spectra Library Searching in Forensic Toxicology. Forensic Science International Journal 113(13): 339-344

\section{Your next submission with Juniper Publishers will reach you the below assets}

- Quality Editorial service

- Swift Peer Review

- Reprints availability

- E-prints Service

- Manuscript Podcast for convenient understanding

- Global attainment for your research

- Manuscript accessibility in different formats

( Pdf, E-pub, Full Text, Audio)

- Unceasing customer service

Track the below URL for one-step submission https://juniperpublishers.com/online-submission.php 